С.І. Климнюк ${ }^{1}$ Л.Б. Романюк ${ }^{1}$, Л.А. Волянська ${ }^{1}$, В.С. Копча ${ }^{1}$, Т.В. Матвієнко ${ }^{2}$ Н.Я. Кравець В.П. Борак ${ }^{1}$

\title{
УДОСКОНАЛЕННЯ АЛГОРИТМУ ДІЙ ЛІКАРЯ ЩОДО ТАКТИКИ ПРИЗНАЧЕННЯ АНТИБІОТИКОТЕРАПІЇ ПРИ ГОСТРИХ РЕСПІРАТОРНИХ ІНФЕКЦІЯХ З ВРАХУВАННЯМ РЕЗУЛЬТАТІВ БАКТЕРІОЛОГІЧНОГО ДОСЛІДЖЕННЯ
}

\author{
${ }^{1}$ Тернопільський державний медичний університет ім. І.Я. Горбачевського, \\ ${ }^{2}$ Комунальне некомерційне підприємство «Центр первинної медико-санітарної допомоги»
}

Питання призначення антибіотиків сімейними лікарями постає досить гостро. Нормативні документи Міністерства охорони здоров'я України, чинні на даний час, що регламентують алгоритм поведінки лікаря, не дають чітких вказівок щодо призначення бактеріологічного дослідження чи відмови від нього. Як відомо, збудниками гострих респіраторних інсрекцій (ГРІ) можуть бути як віруси, так і бактерії. Результати бактеріологічних досліджень при ГРІ та запальних захворюваннях слизової оболонки порожнини рота свідчать, що постійними збудниками є умовно-патогенні бактерії і дуже часто стафрілококи, які є представниками нормальної автохтонної фрлори певного біотопу людини.

Мета роботи - проаналізувати підстави та перспективи вибору тактики призначення антибіотиків при гострих респіраторних захворюваннях, доцільність та інорормативність результатів бактеріологічного дослідження мікробіоти ротоглотки з визначенням чутливості до антибіотиків виділених итамів і врахуванням діючих нормативних документів.

Наведені переваги призначення антибіотикотерапії хворим за результатами бактеріологічного дослідження, що стосуються пацієнта зокрема та мікрофрлори загалом, а саме: запобігання розвитку кишкового дисбіозу, збільшенню кількості полірезистентних итамів представників умовно-патогенної фрлори, зменшення вартості лікування та відповідно - кількості днів непрацездатності. Робота включає дані про застосування основних груп антибіотиків, що використовуються амбулаторно, та особливості їх взаємодії між собою і впливу на макроорганізм. Відображено модифрікований алгоритм дій лікаря первинної ланки обслуговування при ГРІ з урахуванням результатів бактеріологічного дослідження та антибіотикограми.
Висновки. Наведено економічні важелі, що дозволять здешевити комплекс лікування при ГРІ за рахунок обґрунтованої відмови від призначення антибіотиків або застосування їх з урахуванням чутливості збудників, конкурентоспроможність бактеріологічного дослідження порівняно з вірусологічним та імунологічним.

Ключові слова: гострі респіраторні інфрекції, антибіотикотерапія, практика сімейного лікаря, бактеріологічне дослідження.

Медична галузь України у процесі реформування впродовж останніх років особливо актуалізує розвиток сімейної медицини, а лікарі загальної практики найчастіше стикаються з ГРІ у будь-якої категорії пацієнтів [1-3]. Експерти ВОО3 відзначають, що ця найпоширеніша в людській популяції група хвороб за останні роки має постійну тенденцію до почастішання. Соціальні причини, пов'язані 3 глобальним процесом урбанізації, тісніші контакти людей практично в будь-якій точці земної кулі та посилення міжконтинентальних міграційних процесів зумовлюють подальше розповсюдження ГРІ.

Клінічні прояви усіх етіологічних фрорм дуже схожі, дифреренціювати їх зазвичай неможливо. Респіраторний синдром виступає провідним і проявляється переважно у топічному (локальному) ураженні дихальних шляхів - фарингіт, ларингіт, трахеїт тощо. Збудниками ГРІ можуть бути як віруси, так і бактерії. Результати бактеріологічних досліджень при ГРІ та запальних захворюваннях слизової оболонки порожнини рота свідчать, що постійними збудниками інфрекцій є умовно-патогенні бактерії: стасріло- і стрептококи, інші аеробні та анаеробні умовно-патогенні коки, представники кишкової групи та гриби роду Candida $[4,5]$ Важливою особливістю цих видів збудників $€$ трансфрормування їх біологічних властивостей з розвитком антибіоти- 
корезистентних фрорм, що зумовлює різноманітність клінічних фрорм і значно ускладнює лікування. Стрімкий розвиток резистентності багатьох бактерійних патогенів до антибіотиків робить традиційну терапію неефективною. Дисбіоз мікрофрлори носо- та ротоглотки, алергізація організму людини, зниження імунної резистентності тощо призводять до частішої активації власної бактерійної фрлори при вірусних інфекціях, оскільки останні сприяють і місцевому імунодесріциту [4-6].

Алгоритм медичної допомоги населенню, що надається сімейними лікарями, регламентований наказом МО3 України від 16.07.2014 № 499 «Про затвердження та впровадження медико-технологічних документів зі стандартизації медичної допомоги при грипі та гострих респіраторних інсрекціях», переглянутий у 2017 р. та чинний на даний час. Згідно з цим документом сімейний лікар встановлює топічний діагноз ураження дихальних шляхів при ГРІ та вирішує питання симптоматичного лікування і стратегії антибіотикотерапії. Оскільки деякі форми ГРІ (гострий риносинусит, гострий середній отит, гострий фрарингіт і тонзиліт, ларингіт, трахеїт, бронхіт та бронхіоліт) здатні до самоліквідації без лікування, то в більшості випадків немає клінічної потреби в ідентифікації збудника та призначенні антибіотикотерапії. Епідемічний процес при ГРІ, спричинений невірусними збудниками, значно складніший внаслідок не стільки великого етіологічного розмаїття, скільки за рахунок різного рівня контагіозності, меншої сприйнятливості людини, можливості збереження збудників не лише в людській популяції, але й серед тварин [2-4].

Більшість ГРІ, навіть за відсутності антибактерійного лікування, завершується одужанням, а ускладнення за відсутності антибіотикотерапії малоймовірні. Сімейний лікар повинен призначити лікування залежно від ступеня тяжкості хвороби, належності пацієнта до певних груп ризику та враховуючи вподобання пацієнта щодо стратегії антибіотикотерапії. Останній фракт звучить досить неконкретно, оскільки пацієнти в основній масі некомпетентні стосовно свого мікробіологічного статусу в ділянці рото- та носоглотки. На нашу думку, в алгоритм опитування пацієнта слід включити збір інформації про попередні бактеріологічні дослідження та попереднє застосування антибіотиків, яка дасть змогу сімейному лікарю чіткіше зорієнтуватись стосовно призначення антибіотикотерапії. Для прикладу: носійство стасрілокока у здорових осіб, за даними ВООЗ, становить 30-50 \%, за іншими джерелами - близько $20 \%$ населення є постійними носіями золотистого стафілокока. При цьому бактерія не викликає в них ніяких симптомів. Здорове носійство S. aureus у нижніх носових ходах спостерігається у 70-90 \% обстежених, у деяких з них (20\%) воно може тривати постійно [7]. Для здорової людини ці коки, які належать до нормобіоти організму, не становлять небезпеки, але в разі зниження реактивності імунної сис- теми стафрілококи стають збудниками різних захворювань та ускладнень.

Нераціональне призначення антибіотиків призводить до медикаментозно-індукованих побічних ефектів, розповсюдження стійких до антибіотиків мікроорганізмів у довкіллі та збільшення кількості первинних медичних консультацій через хвороби, що здатні до самовиліковування [3, 4]. Суттєво обмежує есрективність $\beta$-лактамів повсюдне поширення штамів бактерій, які продукують пеніцилінази, цесралоспоринази. Тому при тяжких бактерійних ускладненнях грипу доцільно передусім застосовувати захищені інгібіторами $\beta$-лактамаз пеніциліни чи цефалоспорини, аміноглікозиди III покоління, а також макроліди III генерації (не поєднувати з пеніцилінами і цефалоспоринами, які $є$ антагоністами). Високоефективними, у тому числі при нозокоміальних інфекціях, є оксазолідинони (в Україні зареєстрований лінезолід), які цілком позбавлені перехресної резистентності з іншими антибіотиками, однак діють тільки на грампозитивні бактерії, анаеробні бактероїди і клостридії. Препаратами вибору можуть бути «респіраторні» фрторхінолони III-IV поколінь, які мають високу антибактерійну активність і широкий спектр дії, у тому числі на полірезистентні грамнегативні та грампозитивні бактерії. Найширший спектр дії мають карбапенеми (тієнаміцини) [8].

На практиці нерідко зловживають антибіотиками. Разом з тим, розроблені чіткі клінічні показання до їх використання: 1) дуже тяжкий ступінь грипу (гіпертоксична форма 3 енцефалітними явищами, початок пневмонії), 2) грип у дітей перших 2 років життя, вагітних, різко ослаблених, осіб похилого і старечого віку, 3) бактерійні ускладнення, 4) супутні хронічні захворювання, які можуть загостритись під впливом грипу. У решті випадків антибіотики протипоказані, бо вони підсилюють алергізацію організму, пригнічують утворення протигрипозних антитіл, підвищують частоту різних ускладнень [4].

Для пацієнтів з ГРІ при первинній медичній допомозі або першому зверненні за допомогою (наприклад, при наданні невідкладної допомоги) можуть бути використані три стратегії лікування:

- відмова від антибіотиків,

- відкладене у часі призначення антибактерійних препаратів (їх застосування дозволяється через певний проміжок часу в разі погіршення клінічного стану або відсутності позитивної динаміки),

- негайне їх призначення.

Спільне рішення лікаря і пацієнта стосовно необхідності призначення антибактерійних препаратів і вибору стратегії антибіотикотерапії залежить як від оцінки лікарем ризику розвитку ускладнень у разі утримання від антибіотикотерапії, так і від очікувань пацієнта на їх призначення. У п. 3.1.3. наказу МОЗ України від 16.07.2014 № 499, що стосується діагностики ГРІ, мазок із слизової оболонки носа 


\section{КОРОТКІ ПОВІДОМЛЕННЯ}

та ротоглотки на бактеріологічне обстеження віднесено до додатково рекомендованих поряд із обстеженням на віруси грипу. Враховуючи те, що тривалість основних проявів ГРІ коливається в межах від 4 діб до 3-х тижнів, результати бактеріологічного дослідження з визначенням антибіотикочутливості, що будуть отримані не пізніше 3-ї доби від забору матеріалу, досить вагомо допоможуть сімейному лікарю у випадку відкладеного у часі призначення антибактерійних лікарських засобів. Порівнювати діагностичну цінність бактеріологічного та вірусологічного дослідження з врахуванням їх вартості та потенційних можливостей регіональних і місцевих лабораторій відносно відкладеного у часі призначення антибактерійних лікарських засобів досить проблематично.

На користь включення бактеріологічного дослідження у комплекс діагностичного пошуку при ГРІ свідчать мікробіологічні критерії:
- наявність вікових особливостей складу мікросрлори носо- та ротоглотки у дітей різного віку та дорослих;

- варіабельність властивостей умовно-патогенної мікрофрлори у віковому аспекті;

- зміни видового складу біотопу ротоглотки при вірусних інфрекціях;

- антибіотикочутливість як індивідуальна видова характеристика мікроорганізму у кожного пацієнта;

- ризик розвитку антибіотикорезистентності умовнопатогенної фрлори, при необґрунтованому застосуванні антибіотиків хворим на ГРВІ;

- розвиток ускладнень антибіотикотерапії, зокрема, дисбактеріозу ротоглотки та кишечнику.

Враховуючи усі позитивні та негативні висліди при застосуванні антибіотиків, алгоритм дій лікаря при ГРІ слід модифрікувати стосовно пункту узгодження стратегії антибіотикотерапії (мал. 1).

\begin{tabular}{|c|c|c|c|}
\hline \multicolumn{4}{|c|}{ Отримати дані про пацієнта: ПІБ, адреса проживання } \\
\hline \multicolumn{4}{|c|}{$\downarrow$} \\
\hline \multicolumn{4}{|c|}{$\begin{array}{c}\text { Збір анамнезу: скарги, чим лікувався, анамнез попередніх захворювань, фрактори ризику, } \\
\text { супутні хвороби, алергологічний анамнез, бактеріологічний анамнез }\end{array}$} \\
\hline \multicolumn{4}{|c|}{$\downarrow$} \\
\hline \multicolumn{4}{|c|}{ 3'ясувати очікування пацієнта щодо антибіотикотерапії } \\
\hline$\downarrow$ & \multicolumn{3}{|c|}{$\downarrow$} \\
\hline \multirow[t]{9}{*}{$\begin{array}{c}\text { Надати інсрормацію про звичайний } \\
\text { перебіг і середню тривалість } \\
\text { хвороби }\end{array}$} & \multicolumn{3}{|c|}{ Надати поради щодо симптоматичного лікування } \\
\hline & \multicolumn{3}{|c|}{$\downarrow$} \\
\hline & \multicolumn{3}{|c|}{ Узгодження стратегії антибіотикотерапії } \\
\hline & $\downarrow$ & \multicolumn{2}{|l|}{$\downarrow$} \\
\hline & $\begin{array}{l}\text { Наявність ризику розвитку } \\
\text { ускладнень }\end{array}$ & \multicolumn{2}{|c|}{$\begin{array}{c}\text { Інфоромування про можливості, строки прове- } \\
\text { дення та діагностичне значення бактеріологіч- } \\
\text { ного дослідження }\end{array}$} \\
\hline & $\downarrow$ & \multicolumn{2}{|l|}{$\downarrow$} \\
\hline & $\begin{array}{c}\text { Негайне призначення } 3 \\
\text { попереднім забором матеріа- } \\
\text { лу для бакдослідження }\end{array}$ & \multicolumn{2}{|c|}{$\begin{array}{c}\text { Забір матеріалу для бактеріологічного } \\
\text { дослідження та очікування його результатів }\end{array}$} \\
\hline & & $\downarrow$ & $\downarrow$ \\
\hline & & $\begin{array}{c}\text { Відкладене призначення } 3 \\
\text { врахуванням антибіотико- } \\
\text { грами }\end{array}$ & $\begin{array}{l}\text { Відмова від } \\
\text { антибіотиків }\end{array}$ \\
\hline
\end{tabular}

Мал. 1. Алгоритм дій лікаря при гострих респіраторних інфекціях з врахуванням результатів бактеріологічного дослідження.

Проаналізувавши рекомендації щодо лікування ГРІ у дорослих і дітей, слід зазначити, що необхідним є призначення бактеріологічного дослідження у кожному випадку клінічної постановки діагнозу ГРІ з таких причин:

по-перше - бактеріологічне дослідження дає інсрормацію про кількісний та якісний склад мікрофрлори ротоглотки, а отже - можливість достовірного прогнозу ризику розвитку бактерійних ускладнень з урахуванням ролі умовно-патогенної фрлори;

по-друге - забір матеріалу (незалежно чи це виклик на дім чи відвідування хворим амбулаторії сімейної медицини) не становить жодних труднощів ні для персоналу, ні для 
пацієнтів, а строки отримання результатів бакдослідження вкладаються в рекомендації МОЗу щодо призначення антибіотикотерапії;

по-третє - результати антибіотикограми дозволять лікуючому лікарю при потребі призначити антибіотики не емпірично, а прицільно, індивідуально для кожного пацієнта, знизивши вірогідність розвитку дисбіозу кишечнику (основна маса антибіотиків, що призначаються амбулаторно, є пероральними) та резистентності сапрофрітної мікросрлори кожного пацієнта, а також зменшити ризик збільшення циркуляції антибіотикорезистентних штамів у популяції загалом.

У світлі комерціалізації медичних послуг не останню роль відіграє й економічна складова комплексу діагностики та лікування ГРІ з урахуванням даних бакдослідження, a саме: співвідношення затрат на його проведення та зменшення вартості лікування конкретного пацієнта за рахунок:

- скорочення терміну непрацездатності внаслідок запобігання розвитку ускладнень, а стосовно дітей, - то і перебування на листку непрацездатності з догляду за ними;

- зменшення вартості лікування за рахунок підвищення есрективності антибіотикотерапії через спрямовану дію;

- зменшення витрат на компенсацію побічної дії антибіотиків на травний канал з урахуванням фрункціональних і бактеріологічних змін.

Таким чином, бактеріологічне дослідження можна вважати більш обґрунтованим 3 етіологічної точки зору при ГРІ, ніж визначення різновиду вірусів та комплекс загальноклінічних обов'язкових обстежень, що дають лише орієнтовну картину про стан організму в цілому.

\section{Література}

1. Ткаченко В.І. Лікування гострих респіраторних інфееццій у практиці сімейного лікаря / В.І. Ткаченко, Х.М. Кухарчук, К.В. Бабіченко // Семейная медицина. - 2015. - № 3(59). - С. 98-102.

2. Наказ МОЗ України від 16.07.2014 № 499 «Про затвердження та впровадження медикотехнологічних документів зі стандартизації медичної допомоги при грипі та гострих респіраторних інсрекціях». - Режим доступу: http://www.dec.gov.ua/mtd/reestr.html

3. Наказ МОЗ України № 590 від 12.08.2009 р. «Про затвердження методичних рекомендацій «Принципи діагностики та лікування хворих на гострі респіраторні вірусні захворювання». - Режим доступу: http://www.moz.gov.ua/ua/portal/dn_20090812_590.html

4. Удосконалення лікування хворих на грип та інші ГРВІ / М.А. Андрейчин, В.С. Копча, В.Д. Москалюк [та ін.] // Інфекційні хвороби. - 2013. - № 2(72). - С. 12-19.

5. Нові можливості поліпшення лікування респіраторних захворювань у дітей, які часто і тривало хворіють / Л.А. Волянська,
Л.Б. Романюк, Н.Ю. Щербатюк [та ін.] // Актуальні питання педіатрії, акушерства та гінекології. - 2011. - № 2. - С. 97-99.

6. Нудченко О. Гострі респіраторні інфрекції. Уніфрікований клінічний протокол первинної медичної допомоги дорослим та дітям / О. Нудченко // Электронный научно-популярный журнал про семейную медицину. - 2014. - Режим доступу: http://www.webmedfamily. org/index.php/normativnaya-baza/mediko-tekhnologicheskayadokumentatsiya/186-gostri-respiratorni-infektsiji-unifikovanij-klinichnijprotokol-pervinnoji-medichnoji-dopomogi-doroslim-ta-dityam

7. Характеристика стафрілококів та їх роль у патології дітей / М.А. Гарифуліна, О.С. Воронкова, Т.М. Шевченко, А.І. Вінніков // Вісник Дніпропетровського університету: Біологія. Медицина. 2014. - № 5(2). - С. 115-120.

8. Сучасні антибіотики та принципи раціональної антибіотикотерапії (частина I) / В.С. Копча, М.А. Андрейчин, О.В. Давидович [та ін.] // Інфрекційні хвороби. - 2011. - № 4(66). - С. 55-71.

\section{References}

1. Tkachenko, V.I., Kukharchuk, Kh.M., \& Babichenko, K.V. (2015) Likuvannia hostrykh respiratornykh infektsii u praktytsi simeinoho likaria [Treatment of acute respiratory infection in home doctor practice]. Semeynaya Meditsina, 3 (59), 98-102 [in Ukrainian].

2. Nakaz MOZ Ukrainy vid 16.07.2014 N 499 «Pro zatverdzhennia ta vprovadzhennia medykotekhnolohichnykh dokumentiv zi standartyzatsii medychnoi dopomohy pry hrypi ta hostrykh respiratornykh infektsiiakh» [Order of the Ministry of Health of Ukraine dated 07/16/2014 N 499 «On Approval and Implementation of Medical Technology Documents for the Standardization of Medical Aid in the Case of Influenza and Acute Respiratory Infections»]. [E-resource]. Retrieved from: http:// www.dec.gov.ua/mtd/reestr.html [in Ukrainian].

3. Nakaz MOZ Ukrainy N 590 vid 12.08.2009 r. «Pro zatverdzhennia metodychnykh rekomendatsii «Pryntsypy diahnostyky ta likuvannia khvorykh na hostri respiratorni virusni zakhvoriuvannia» [Order of the Ministry of Health of UkraineN 590 dated August 12, 2009 «On Approval

of Methodological Recommendations» Principles of Diagnosis and Treatment of Acute Respiratory Viral Disease Patients"]. [E-resource]. Retrieved from: http://www.moz.gov.ua/ua/portal/dn_20090812_590. $\mathrm{html}$

4. Andreichyn, M.A., Kopcha, V.S., Moskaliuk, V.D., Hirina, O.M., \& losyk, Ya.I. (2013). Udoskonalennia likuvannia khvorykh na hryp ta inshi HRVI [Treatment improvement in patients with influenza and other ARVI]. Infektsiini khvoroby, 2 (72), 12-19 [in Ukrainian].

5. Volianska, L.A., Romaniuk, L.B., Shcherbatiuk, N.Yu., Hulevska, A.P., Nedoshytko, H.I., \& Chubata, O.B (2011). Novi mozhlyvosti polipshennia likuvannia respiratornykh zakhvoriuvan u ditei, yaki chasto $i$ tryvalo khvoriiut [New ways of improving the treatment of respiratory diseases in children, who often and for the long ill]. Aktualni pytannia pediatrii, akusherstva ta hinekolohii, 2, 97-99 [in Ukrainian].

6. Nudchenko, O. (2014). Hostri respiratorni infektsii. Unifikovanyi klinichnyi protokol pervynnoi medychnoi dopomohy doroslym ta ditiam 
[Acute respiratory infections. Unified clinical protocol for primary care for adults and children]. Elektronnyy nauchno-populyarnyy zhurnal pro semeynuyu meditsinu [E-resource]. Retrieved from: http://www.webmedfamily.org/index.php/normativnaya-baza/medikotekhnologicheskaya-dokumentatsiya/186-gostri-respiratorni-infektsijiunifikovanij-klinichnij-protokol-pervinnoji-medichnoji-dopomogidoroslim-ta-dityam

7. Haryfulina, M.A., Voronkova, O.S., Shevchenko, T.M., \& Vinnikov, A.I. (2014). Kharakterystyka stafilokokiv ta yikh rol u patolohii ditei [Characteristic of Staphylococci and their role in children patology]. Visnyk Dnipropetrovskoho universytetu: biolohiia. Medytsyna, 5 (2), 115-120 [in Ukrainian].

8. Andreichyn, M.A., Kopcha, V.S., Davydovych, O.V., Davydovych, N.Ya., Leheza, K.,M., \& Shpikula, N.H. (2011). Suchasni antybiotyky ta pryntsypy ratsionalnoi khimioterapii (chactyna I) [Modern antibiotics and principles of rational antibiotictherapy (part I)]. Infektsiini khvoroby, 4 (66), 55-71 [in Ukrainian].

\section{ALGORITHM OF DOCTOR'S ACTION IMPROVEMENT FOR PRESCRIBING ANTIBIOTIC THERAPY FOR THE TREATMENT OF PATIENTS WITH ACUTE RESPIRATORY INFECTIONS TAKING INTO CONSIDERATION THEIR BACTERIOLOGICAL EXAMINATION}

S.I. Klymniuk ${ }^{1}$, L.B. Romaniuk ${ }^{1}$, L.A. Volianska ${ }^{1}$, V.S. Kopcha ${ }^{1}$, T.V. Matviienko², N.Ya. Kravets ${ }^{1}$, V.P. Borak ${ }^{1}$

${ }^{1}$ I. Horbachevsky Ternopil State Medical University, ${ }^{2}$ Communal Nonprofit Enterprise "Center of Primary Health Care"

SUMMARY. Acute respiratory infections (ARIs) are common in the practice of a family doctor, so the appointment of antibiotic therapy is very important. Normative documents of the Ministry of Health of Ukraine regulating the physician's behavior algorithm do not provide clear indications as to the purpose or not of the appointment of a bacteriological examination. The causes of such infections may be both viruses and bacteria. The results of bacteriological studies in ARIs and inflammatory diseases of the oral mucosa indicate that pathogenic bacteria, namely staphylococci, which are representatives of a normal autochthonous microflora of a specific human biotope, are constant pathogens of infections.

The aim of the work - to analyse the bases and prospects of choosing tactics of antibiotics appointment in acute respiratory diseases under the condition of three different algorithms of therapy, expediency and informativeness of the results of the bacteriological examination of the microbiotit oral cavity and nasopharynx with the determination of the sensitivity to the antibiotics of isolated strains and taking into account existing normative documents. The advantages of appointing antibiotic therapy to patients according to the results of bacteriological studies concerning the patient in particular and the microflora in general, namely: preventing the development of intestinal dysbiosis, preventing an increase in the number of polysaccharides strains of the conditionally pathogenic flora, reducing the cost of treatment and, accordingly, the number of days on the disability sheet. The work includes data on the use of the main groups of antibiotics used in outpatient and the features of their interaction with each other and the impact on macroorganism. A modified algorithm of the primary care physician's treatment in acute respiratory infections is presented, taking into account the results of bacteriological research and antibioticograms.

Conclusions. Economic levers are suggested, which will allow to reduce the cost of a complex of treatment at the ARIs due to the reasonable not the purpose of antibiotics, or their application taking into account the sensitivity of pathogens, the competitiveness of bacteriological research in comparison with the virological and immunological in respiratory infections.

Key words: acute respiratory infections; antibiotic therapy; practice of family doctor; bacteriological examination.

\section{Відомості про авторів:}

Климнюк С.І. - д. мед. н., професор, завідувач каседри мікробіології, вірусології та імунології ДВНЗ «ТДМУ імені І.Я. Горбачевського МОЗ України»; klymnyuk@yahoo.com

Романюк Л.Б. - к. мед. н., доцент кафедри мікробіології, вірусології та імунології дВНЗ «ТДМУ імені І.Я. Горбачевського МОЗ України»; romanyuk@ tdmu.edu.ua

Волянська Л.А. - канд. мед. н., доцент каседри дитячих хвороб з дитячою хірургією ДВНЗ «ТДМУ імені І.Я. Горбачевського МОЗ України»; volyanska@ tdmu.edu.ua

Копча В.С. - д. мед. Н., просресор кафедри інсрекційних хвороб з епідеміологією, шкірними та венеричними хворобами ДВНЗ «ТДМУ імені І.Я. Горбачевського МОЗ України»; kopcha@ukr.net

Матвієнко Т.В. - сімейний лікар вищої категорії комунального некомерційного підприємства «Центр первинної медико-санітарної допомоги», завідувач амбулаторії загальної практики сімейної медицини № 11; kravecnj@tdmu. edu.ua 


\section{КОРОТКІ ПОВІДОМЛЕННЯ}

Кравець Н.Я. - к. біол. н., асистент кафредри мікробіології, вірусології та імунології ДВНЗ «ТДМУ імені І.Я. Горбачевського МO3 України»; kravecnj@tdmu.edu.ua

Борак В.П. - к. мед. н., асистент касредри мікробіології, вірусології та імунології ДВНЗ «ТДМУ імені І.Я. Горбачевського МОЗ України»; borak@tdmu.edu.ua

\section{Information about authors:}

Klymnyiuk S. - MDS, Professor, the head of the Department of Microbiology, Virology and Immunology of I. Horbachevsky Ternopil State Medical University; klymnyuk@ yahoo.com

Romaniuk L. - PhD, Associated Professor, of the Department of Microbiology, Virology and Immunology of I. Horbachevsky Ternopil State Medical University; romanyuk@ tdmu.edu.ua

Volianska L. - PhD, Associated Professor of the Department of Children's Diseases with Pediatric Surgery of I. Horbachevsky Ternopil State Medical University; volyanska@ tdmu.edu.ua

Kopcha V. - MDS, professor of the Department of Infectious Diseases and Epidemiology, Skin and Venereal Illnesses of I. Horbachevsky Ternopil State Medical University; kopcha@tdmu.edu.ua

Matviienko T. - family doctor of the highest category of Communal Nonprofit Enterprise «Center of Primary Health Care», Head of the Ambulatory General Practice of Family Medicine N 11; kravecnj@tdmu.edu.ua

Kravets N. - PhD, assistant of the Department of Microbiology, Immunology and Virology of I. Horbachevsky Ternopil State Medical University; kravecnj@tdmu.edu.ua

Borak V. - PhD, assistant of the Department of Microbiology, Immunology and Virology of I. Horbachevsky Ternopil State Medical University; borak@tdmu.edu.ua

Конфрлікт інтересів: немає.

Authors have no conflict of interest to declare.

Отримано 22.01.2018 p.

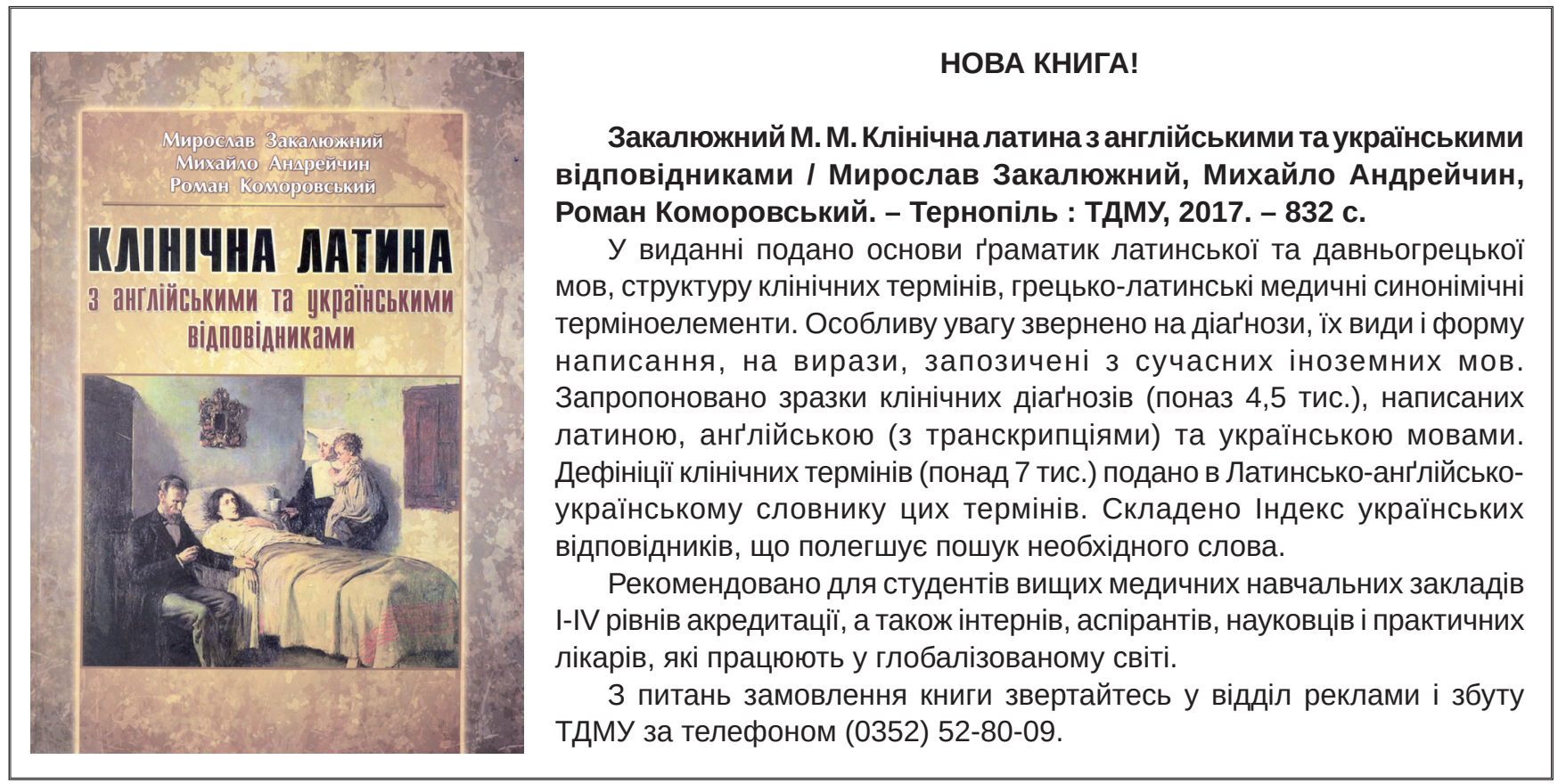

